\title{
Antitumour Activity of Dinitrosyl Iron Complexes with Thiol-Containing Ligands in Animals: An Overview
}

Vanin $\mathrm{AF}^{1,2 *}$, Ostrovskaya $\mathrm{LA}^{2}$ and Korman $\mathrm{DB}^{3}$ ${ }^{1}$ N.N. Semenov Institute of Chemical Physics, Russian Academy of Sciences, Moscow, Russia

${ }^{2}$ Institute of Regenerative Medicine, I.M. Sechenov First Moscow State Medical University, Moscow, Russia ${ }^{3}$ N.M. Emanuel Institute of Biochemical Physics, Russian Academy of Sciences, Moscow, Russia

*Correspondling author: Anatoly F Vanin, N.N. Semenov Institute of Chemical Physics, Russian Academy of Sciences, Institute of Regenerative Medicine, I.M. Sechenov First Moscow State Medical University, Moscow, Russia

Received: J uly 25, 2018; Accepted: September 12, 2018; Published: September 19, 2018

\begin{abstract}
The data reviewed herein strongly suggest that binuclear dinitrosyl iron complexes (DNIC) with glutathione can fully (by 100\%) suppress the growth of rapidly proliferating nonmalignant endometrial tumours in rats with experimental endometriosis, on the one hand, and retard the growth of transplanted malignant solid tumours (Lewis lung carcinoma), on the other hand. An inverse correlation was established between the antitumour effect of DNIC with glutathione on Lewis carcinoma and the mode of DNIC administration (intraperitoneal or intravenous). In the former case, the maximum inhibition of tumour growth was achieved by treatment of animals with the highest $(200 \mu \mathrm{moles} / \mathrm{kg})$ dose of DNIC, while after intravenous administration the inhibiting effect of DNIC increased with a decrease of the drug dose to $2 \mu \mathrm{moles} / \mathrm{kg}$. It was suggested that Lewis carcinoma cells respond to DNIC used as a nitric monoxide (NO) donor by the development of a system of antinitrosative protection similar to that formed in many bacterial species in response to treatment with NO or its derivatives. It is not excluded that DNIC with thiol-containing ligands can fully suppress tumour growth when used as a nitrosonium (NO+) ion (but not NO) donor, as could be evidenced from the results of recent studies by Prof. Liaw et al. [Inorg. Chem. 2016, 55, 9383].
\end{abstract}

Keywords: Dinitrosyl iron complexes; Nitric oxide; Cancer; Experimental endometriosis; Apoptosis

\section{Abbreviations}

AAF: 2-acetylaminofluorine; B- or M-DNIC: Binuclear or Mononuclear Dinitrosyl Iron Complexes; EDTA: Disodium Ethylenediaminetetraacetate; EMT: Endometrial Tumour; EPR: Electron Paramagnetic Resonance; GSH: Glutathione; GS-NO: S-nitrosoglutathione; MGD: N-methyl-D-glucamine Dithiocarbamate; MNIC-MGD: Mononitrosyl Iron Complexes with MGD.

\section{Introduction}

The discovery of the unique capability of nitric monoxide (NO), the simplest chemical compound produced from L-arginine by enzymatic route, to exert beneficial (regulatory) effects on an immense diversity of metabolic processes occurring in human and animal organisms and its role of a key effector of cell-mediated immunity has opened up an outstanding opportunity for a detailed study of mechanisms of cytotoxic effects of NO with the main emphasis on the development, on its basis, of a vast array of potent new-generation drugs able to suppress the growth and proliferation of malignant tumours [1-6].

However, despite considerable efforts in this area [7-18], these expectations are not yet realized, and no major breakthrough has come about. By now, it has been established that in animal organisms $\mathrm{NO}$ can initiate both death and enhanced proliferation of normal and malignantly transformed cells and tissues. These effects are manifested at high (hundreds of micromoles and higher) concentrations of NO, while at low (micromolar) concentrations $\mathrm{NO}$ enhances tumour growth. This circumstance seems to be the main reason for the hitherto unsuccessful attempts of drug designers to develop, on the basis of NO, highly effective medicinal drugs able to exert potent and, which is even more important, irreversible inhibiting effects on tumour growth in animals.

Besides, it is still unclear whether NO synthesized from L-arginine by enzymatic route is present in animal tissues in the free form or as a constituent of chemical compounds responsible for its stabilization, transfer to biological targets and evacuation from the organism.

The aim of the present review is to demonstrate, on the basis of experimental evidence obtained thus far, that dinitrosyl iron complexes (DNIC) with thiol-containing (RS-) ligands including natural thiols (glutathione and L-cysteine) hold considerable promise as candidate medicinal drugs endowed with a unique capability to influence both normal and malignantly transformed cells and tissues.

Previous studies have shown that in animal cells DNIC are formed in the presence of endogenous and exogenous $\mathrm{NO}$ and are represented predominantly by the binuclear (diamagnetic) form (B-DNIC) with the chemical formula $\left[\left(\mathrm{RS}^{-}\right)_{2} \mathrm{Fe}_{2}{ }^{+}\left(\mathrm{NO}^{+}\right)_{4}\right]$. In living organisms, the binuclear form of DNIC occurs in parallel with the mononuclear (paramagnetic) form (M-DNIC), which has the formula [(RS- $)_{2} \mathrm{Fe}^{+}\left(\mathrm{NO}^{+}\right)_{2}$ ] and is EPR-detectable [19-27].

Both forms of DNIC with thiol-containing ligands play the role of donors of $\mathrm{NO}$ and nitrosonium ions $\left(\mathrm{NO}^{+}\right)$[21-27]. Their interaction with heme- and thiol-containing proteins gives nitrosyl heme-containing complexes and S-nitrosothiols, respectively. The 
Table 1: Regulatory effects of DNIC with thiol-containing ligands on various physiological processes.

\begin{tabular}{|c|c|c|}
\hline 1 & Potent vasodilating and hypotensive effects & $28-32$ \\
\hline 2 & Inhibition of platelet aggregation & 33 \\
\hline 3 & Increased elasticity of red blood cells & 34 \\
\hline 4 & Accelerated healing of skin wounds & 35,36 \\
\hline 5 & Increased survival in animals with hemorrhagic shock & 37 \\
\hline 6 & Penile erectile effect & 38 \\
\hline 7 & Reduction of the size of the necrotic zone in experimental & 39 \\
\hline 8 & myocardial infarction & 40 \\
\hline 9 & Antiapoptotic effect on cultured normal human and animal cells & $41-46$ \\
\hline 10 & Antioxidant effects & 47,48 \\
\hline
\end{tabular}

Table 2: Cytotoxic effects of DNIC with thiol-containing ligands.

\begin{tabular}{|c|c|c|}
\hline 1 & $\begin{array}{c}\text { Proapoptotic effect on HeLa cells in the presence of exogenous iron } \\
\text { chelators }\end{array}$ & 49 \\
\hline 2 & Proapoptotic effect on Jurkat cells & 50 \\
\hline 3 & $\begin{array}{c}\text { Inhibition of growth of endometrial tumours in animals with } \\
\text { experimental endometriosis }\end{array}$ & $51-53$ \\
\hline 4 & Inhibition of tumour growth at early stages of malignization & $54-56$ \\
\hline 5 & Cytotoxic effect on Coxsackie B. virus in myocardial tissues & 57 \\
\hline
\end{tabular}

biological activity of heme- and thiol-containing proteins increases or decreases under the action of $\mathrm{NO}$ and $\mathrm{NO}^{+}$, which determines the overall effect of DNIC on physiological and biochemical processes occurring in animal organisms. It is by this mechanism that DNIC exert a dual effect one of which is beneficial (regulatory) and the other one is deleterious (cytotoxic). At low (1-2 $\mu$ moles $/ \mathrm{kg})$ doses, DNIC produce a beneficial effect, while at higher $(\geq 150-200 \mu \mathrm{moles} / \mathrm{kg})$ doses it is the cytotoxic effect that comes to the foreground [25].

The novel therapeutic drug "Oxacom" in which DNIC with glutathione were used as the active substance was designed recently by a group of researchers at the Russian Cardiology Researchand-Production Complex [28]. The drug successfully underwent pharmacological testing. Its lethal $\mathrm{i} / \mathrm{v}$ dose $\left(\mathrm{LD}_{50}\right)$ for mice and rats was found to be equal to $\sim 140$ and $130 \mu$ moles of B-DNIC $/ \mathrm{kg}$, respectively (as calculated per one iron atom in B-DNIC). Oxacom had no appreciable effect on different cell populations of rabbit blood either upon single i/v administration or after long-term treatment of animals with the drug; mutagenic effects of the latter on bone marrow cells of mice and rats were also absent. Intraperitoneal treatment of pregnant rats $(\mathrm{n}=20)$ with Oxacom (daily, for 1-19 days) did not influence the number and mass of newborn rats, nor did the drug induce any significant pathological changes in the latter. These data altogether testify to complete therapeutic safety of Oxacom on experimental animals.

The results of pharmacological testing of Oxacom, which demonstrated very low toxicity of the novel drug for experimental animals, prompted us the idea to examine its hypotensive effect in a clinical study on 14 healthy male volunteers (aged 21-45) having normal arterial pressure and no chronic diseases. Intravenous infusion of Oxacom (3-4 ml) at a dose corresponding to $0.2 \mu$ moles of B-DNIC with glutathione per $\mathrm{kg}$ of body mass caused a significant (by 20\%) and fast (within 3-4 min) drop of systolic and diastolic
Table 3: The results of statistic evaluation of mean volumes of EMT (in $\mathrm{mm}^{3}$ ) (overall data for all animals) [50].

\begin{tabular}{|l|c|cc|}
\hline \multicolumn{1}{|c|}{ Animals } & Median (min-max) & Mean \pm SEM \\
\hline Group 1 & & \\
\hline Control rats $(n=10)$ & $38(2-599)$ & $113 \pm 179$ & \\
\hline Experimental rats $(n=10)$ & $0(0-73)$ & $7 \pm 17 \quad p<0.001$ \\
\hline \multicolumn{1}{|c|}{ Group 2 } & & & \\
\hline Control rats $(n=10)$ & $30(2-866)$ & $150 \pm 230$ & \\
\hline Experimental rats $(n=10)$ & $7(0-759)$ & $106 \pm 23 \quad p<0.008$ \\
\hline
\end{tabular}

pressure from $137 \pm 4$ to $110 \pm 4 \mathrm{~mm} \mathrm{Hg}$ and from $85 \pm 2$ to $61 \pm 4 \mathrm{~mm}$ $\mathrm{Hg}$, respectively. The dynamics of changes in mean arterial pressure (MAP) is shown in Figure 1. In the subsequent period, which varied from 6 to $9 \mathrm{~h}$, both parameters remained at the steady-state (low) level. However, after wakening the patients' blood pressure returned to the initial values [28].

Some examples of beneficial (regulatory) and deleterious (cytotoxic) effects of DNIC with thiol-containing ligands are given in Tables 1 and 2, respectively [29-57].

The description of cytotoxic effects of DNIC on endometrial and malignant tumours will be given in the subsequent chapters.

\section{Cytotoxic Effects of B-DNIC with Glutathione on Nonmalignant (Endometrial) Tumours in Rats with Experimental Endometriosis}

From clinical standpoint, DNIC effects on benign and malignant tumours are classified into beneficial (suppressing tumour growth) and harmful (stimulating this process). For the first time, the beneficial effect of B-DNIC with glutathione on nonmalignant endometrial tumours (EMT) was established in our laboratory for rats with experimental endometriosis induced by surgical implantation of two 2-mm fragments of uterine endometrial (epithelial) tissue onto the inner surface of the abdominal wall [51-53]. One month thereafter, tissue grafts implanted to control rats developed into EMT having an ellipsoidal shape and the axial size of $\sim 10 \mathrm{~mm}$. Tissue samples of several control animals contained small-size secondary EMT localized on the inner surface of the abdominal wall. At more advanced stages, the growth of primary and secondary EMT was retarded: one and a half months after surgery, the EMT size did not exceed 12-15 mm. Two months thereafter, the growth of EMT discontinued.

Intraperitoneal (i/p) treatment of rats (daily, for 10 days) with B-DNIC with glutathione in $0.2 \mathrm{ml}$ saline $(10-12 \mathrm{moles} / \mathrm{kg}$ as calculated per one iron atom) on day 4 after surgery and subsequent keeping of animals on a two-week standard vivarium diet led to complete inhibition of EMT growth in the absolute majority of experimental rats (Table 3, Group 1). In control animals, large-size EMT (mean volume $\leq 110 \mathrm{~mm}^{3}$ ) developed during the first 30 days after surgery.

A similar therapeutic effect of B-DNIC with glutathione was established for Group 2 animals subjected to 10-day treatment. Examination of tissue samples performed one month after surgery displayed the presence of fairly large EMT (Table 3, Group 2). On termination of the treatment course, experimental rats were kept on a standard vivarium diet for $4-5$ days. Treatment of these animals 


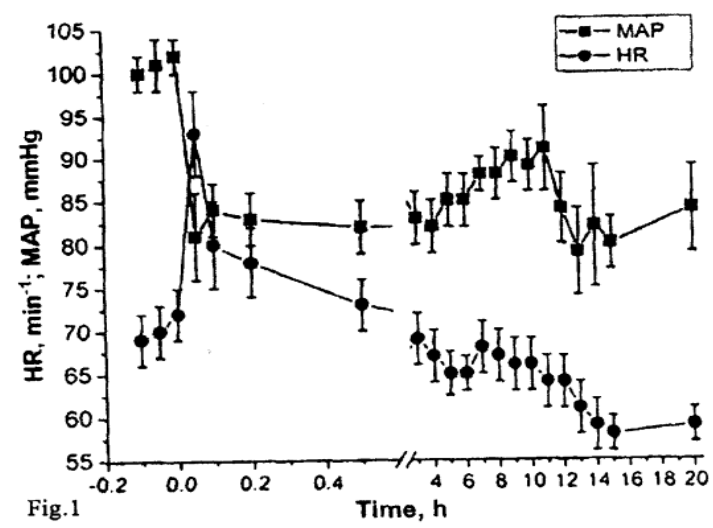

Figure 1: The effects of Oxacom (0.2 $\mu$ moles $/ \mathrm{kg}$ of DNIC-GS) on mean arterial pressure (MAP) and heart rate (HR) in healthy male volunteers [28].

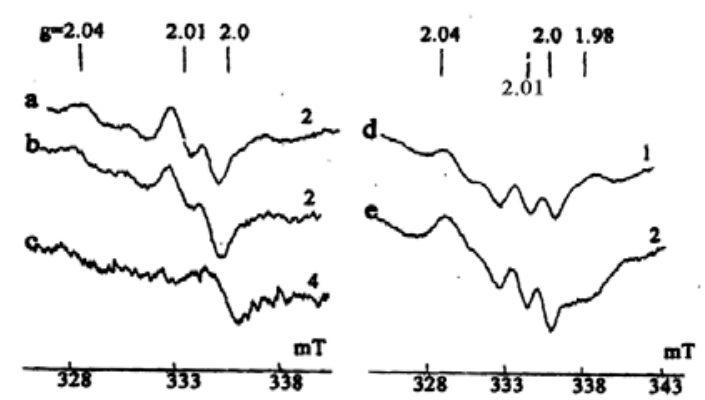

Figure 2: The EPR spectra recorded in EMT tissue samples of control rats $(a, d)$ and of rats treated with GS-NO (b, e) or DNIC with glutathione (c). All EPR spectra were recorded at $77 \mathrm{~K}$. The figures on the right indicate relative amplification of the radiospectrometer [51].

with B-DNIC was accompanied by a drastic decrease of proliferative activity of EMT: histopathological analysis of tissue samples of B-DNIC-treated rats revealed a complete lack of EMT cysts containing rapidly proliferating endometrial cells.

No such effect was found in rats treated with the NO donor S-nitrosoglutathione (GS-NO). In this experimental group, tumour growth was retarded judging from the appearance of multiple adhesions in the abdominal cavity. These adhesions might prevent vascularization of EMT with concomitant suppression of tumour growth. In the absence of adhesions, tumour growth proceeded at abnormally fast rates: after 6 weeks, the size of EMT increased to $1500 \mathrm{~mm}^{3}[51]$.

Prolongation of proliferative activity of EMT in GS-NO-treated rats and its inhibition in B-DNIC-treated animals correlated with the results of EPR analysis of EMT [51]. The EPR spectra of tissue samples of control (untreated) and GS-NO-treated rats obtained at the final stages of the experiment displayed the presence of a doublet EPR signal with a peak at $g=2.01$ characteristic of the active form of ribonucleotide reductase along with an EPR signal with a lowfield component at $\mathrm{g}=2.04$ with a central absorption at $\mathrm{g}=2.03$ (the 2.03 signal) characteristic of M-DNIC with thiol-containing ligands (Figure 2) [51]. The former is often detected in rapidly proliferating tissues and can be used as indicator of enhanced growth of EMT

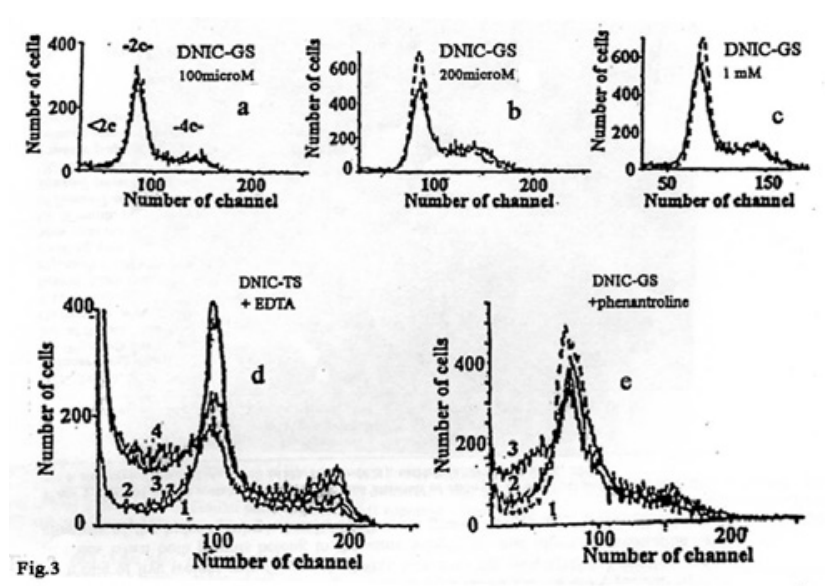

Figure 3: Upper panel: The histograms illustrating the lack of effect of DNIC with glutathione $(a-c)$ on the state of DNA in HeLa cells and the lack of a HeLa subpopulation with DNA content below the diploid level $(<2 c$, late apoptosis) on fluorescence channels with channel number less than 75 DNIC concentrations: $100 \mu \mathrm{M}(\mathrm{a}), 200 \mu \mathrm{M}$ (b) and $500 \mu \mathrm{M}$ (c). Solid line: control; dotted line: incubation with DNIC.

Bottom panel: The histograms illustrating the proapoptotic effect of DNIC with thiosulfate (d) on HeLa cells preincubated in Versene's medium containing $0.5 \mathrm{mM}$ EDTA and DNIC with glutathione after incubation of HeLa cells in Eagle's medium supplemented with fetal calf serum in the presence of bathophenanthroline disulfide (BPDS) (e). Line 1: control; Lines 2-4 (d) DNIC with thiosulphate $(50,100,200$ and $200 \mu \mathrm{M}$, respectively). Lines 2 and 3: $200 \mu \mathrm{M}$ DNIC with glutathione $+50 \mu \mathrm{M}$ BPDS (e). $<2 \mathrm{c},-2 \mathrm{c}$ and $-4 \mathrm{c}$ : Subpopulations of cells with DNA content below the diploid level and with the diploid and tetraploid content of DNA, respectively. Ordinate: cell number (in rel. units) [49].

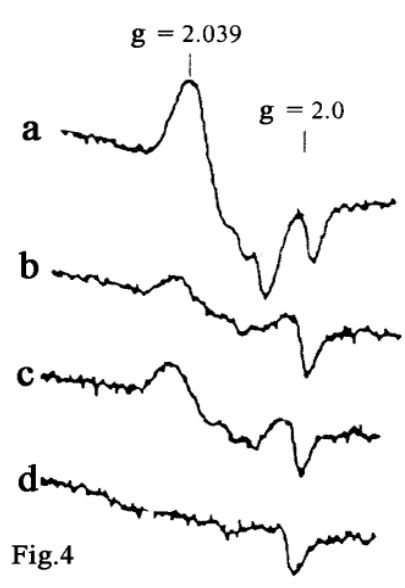

Figure 4: The EPR spectra recorded in 1990's in: (a) activated murine macrophages in the presence of L-arginine; (b) the same in the presence of L-arginine and the NOS inhibitor N-methyl-L-arginine; (c) inactivated control macrophages; (d) control macrophages in the presence of $\mathrm{N}$-methylL-arginine [71].

[58]. The characteristic 2.03 signal was suggested as a specific marker of enhanced production of NO by respective tissues [25,26]. It is not excluded that the immune system of experimental animals responds to fast growth of EMT by enhanced production of NO by immunocompetent cells. Detection in EMT samples of an intense EPR signal corresponding to nitrosyl complexes of hemoglobin provided supporting evidence for this hypothesis. This EPR signal 


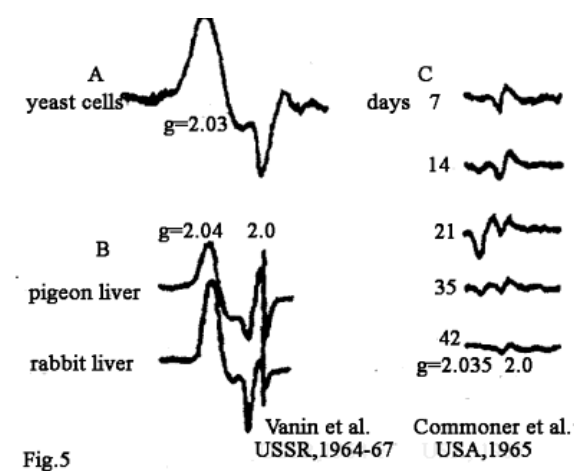

Figure 5: The early recordings of the 2.03 signal in yeast cells (A) [77], in pigeon and rabbit liver cells (B) [78] and in liver tissues of rats fed on a diet enriched with butter yellow ( $p$-dimethylaminoazobenzene) for $7,1421,35$ and 42 days (C) [62].

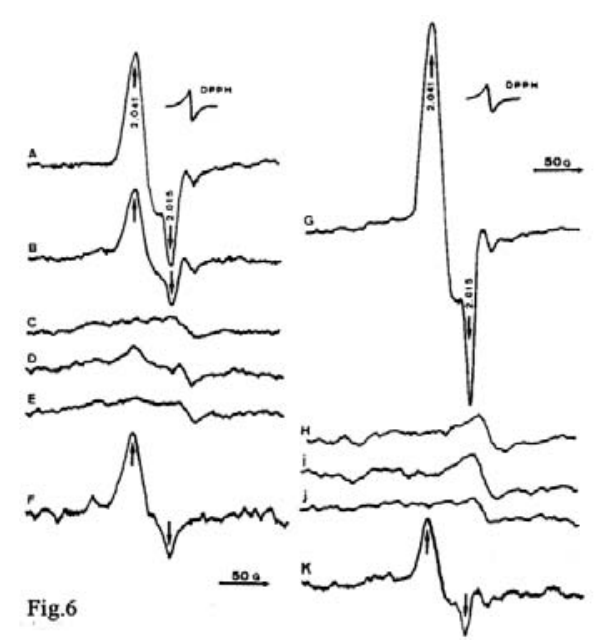

Figure 6: The EPR spectra recorded in target tumor cells of mice (murine leukemia cells L1210) and activated mouse macrophages under different culturing conditions. A, L1210 cells removed from activated macrophages in a cultural medium containing $10 \mathrm{ng} / \mathrm{ml}$ LPS; $\mathbf{B}$, mitochondria from cells as in A; C, L1210 cells after culturing without macrophages in the presence of $10 \mathrm{ng} / \mathrm{ml} \mathrm{LPS}$; $\mathbf{D}$, as $A$, but in the presence of $0.5 \mathrm{mM} \mathrm{N}$-monomethyl-Larginine (MMA) (NOS inhibitor); E, L1210 cells after culturing in an activated macrophage-conditioned medium; F, human K562 leukemia cells removed from activated macrophages in a cultural medium containing $10 \mathrm{ng} / \mathrm{ml}$ LPS; G, L1210 cells after coculturing with IFN--activated macrophages; $\mathbf{H}$, L1210 cells cultured in a medium without macrophages in the presence of 500units/ml IFN-y; I, L1210 cells harvested after $20 \mathrm{~h}$ of coculturing with non-activated macrophages; J, L1210 cells after coculturing with IFN- $\gamma$ activated macrophages in the presence of $0.5 \mathrm{mM}$ MMA; K, IFN- $\gamma$-activated macrophage monolayer. The EPR spectra were recorded at 77K [75].

has a well-resolved triplet hyperfine structure (HFS) with a peak at $\mathrm{g}$ $=2.01$ (Figure 2d,2e). No such EPR signals were found in samples of small-size EMT obtained from B-DNIC-treated rats, the weak EPR signal generated by free radicals at $\mathrm{g}=2.0$ being the only exception (Figure 2c).

Our experiments designed to investigate effects of B-DNIC on EMT in rats with experimental endometriosis were carried out after our discovery of cytotoxic proapoptotic effects of DNIC with glutathione and cysteine on cultured HeLa cells. Noteworthy, these effects were observed only in the presence of iron chelators (bath ophenanthroline disulfonate or EDTA) able to induce effective decomposition of DNIC [48] (Figure 3). Obviously, chelator-induced fast decomposition of DNIC was prerequisite to the appearance in the cultural medium of a considerable amount of NO released from DNIC; high doses of the latter can be responsible for their cytotoxic effect on HeLa cells, most probably, as a result of conversion of $\mathrm{NO}$ into highly toxic peroxynitrite $\left(\mathrm{ONOO}^{-}\right)$in the course of $\mathrm{NO}$ interaction with the superoxide $[59,60]$.

Based on these findings, we conjectured that cytotoxic activity of DNIC towards rapidly proliferating cells and tissues can just as well be manifested in the absence of exogenous iron chelators. As it is known, living systems produce these compounds in order to provide cells and tissues with iron required for their normal functioning [61]. This finding led us to suggest that during incubation of tissue samples with DNIC endogenous iron chelators trigger the release of $\mathrm{Fe}^{2+}$ from DNIC and thus provoke enhanced production of $\mathrm{NO}$ and, as a consequence, selective death of cells and tissues [48,50-52].

For the first time, the selectivity of cytotoxic effects of B-DNIC with glutathione was established in our model studies on rats with experimental endometriosis. However, in this study cytotoxic activity of B-DNIC was specifically directed against EMT without any effect on adjacent organs and tissues including abdominal organs and the intestine. As far as GS-NO whose spontaneous decomposition takes place in the whole volume of the abdominal cavity is concerned, this NO donor was found to affect both tumour and adjacent intact tissues, which manifested itself in the presence of multiple adhesions in the abdominal cavity of EMT rats.

\section{Cytotoxic Effects of B-DNIC with Thiol- containing Ligands on Malignantly Transformed Cells and Tissues}

Taking into account the above-said, it was extremely important for us to investigate the ability of B-DNIC with glutathione to induce death of rapidly proliferating malignant tumours with the same selectivity and efficiency as in the study on rats with experimental endometriosis. The ultimate goal of this study was to develop, on $\mathrm{B}$-DNIC basis, an effective remedy against cancer, one of the most urgent problems in modern-day biology and medicine. This drug must be endowed with the ability to suppress, in one way or another, the proliferative activity of malignantly transformed cells and tissues [60].

A breakthrough in this area was the discovery and identification of DNIC with thiol-containing ligands in the livers of rats treated with various hepatocarcinogenic agents, made in the mid-1960's, by a group of U.S. investigators led by Barry Commoner [62,63]. These authors succeeded in demonstrating the crucial role of DNIC in the pathogenesis of malignant tumours. Further developments in this field $[64,65]$ established that the appearance of DNIC with thiolcontaining ligands in rat liver cells represents a protective response of cells and tissues to malignant transformation. The most important finding of these studies was the establishment of a relationship between the concentration of DNIC or, more specifically, of their mononuclear form (M-DNIC) with a characteristic EPR signal at 2.03 , on the one hand, and the incidence of malignant tumours in experimental animals, on the other hand. 

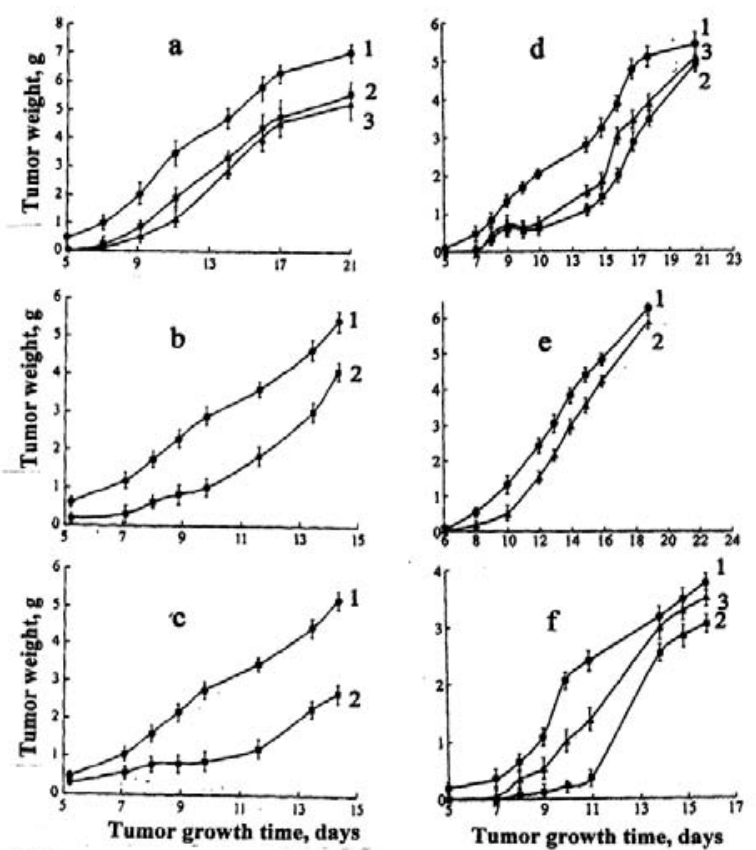

Fig.7

Figure 7: The antitumor effects of $i / p$ injected B-DNIC with glutathione $(a-c)$ and GS-NO $(d, f)$ on murine Lewis lung carcinoma $(a-d)$ or adenocarcinoma

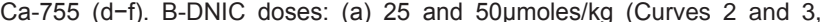

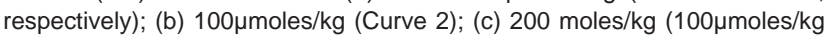
twice a day) (Curve 2); (d) 200 and $400 \mu$ moles/kg of GS-NO (Curves 2 and 3 , respectively); (e) 100 moles/kg of B-DNIC (Curve 2); (f) 200 and $400 \mu$ moles/ $\mathrm{kg}$ of GS-NO (Curves 2 and 3, respectively). Curves 1 - control (without DNIC or GS-NO) [54-56]

In the aforecited studies, the dramatic (nearly tenfold) increase in the intensity of the 2.03 signal recorded in liver samples of rats kept on a nitrite-rich drinking diet supplemented with the hepatocarcinogenic agent 2-acetylaminofluorene (AAF) was followed by a nearly $60 \%$ decrease in the incidence of liver and auricular channel tumours in comparison with rats fed on AAF alone [64]. A similar decrease in the incidence of hepatic tumours induced in $p$-dimethylaminoazobenzene-treated rats by one of DNIC derivatives, viz., Roussin's black salt, is described in [65].

The mechanism of antitumour effects of DNIC became comprehensible after the discovery by Hibbs et al. and, later on, by other investigators [1-6,66-71] that cytotoxic activity of immunocompetent cells, which is specifically directed against malignantly transformed cells and tissues, is under a strict control of NO. The latter is generated from L-arginine in appreciable amounts by activated macrophages in the presence of iNOS (the inducible form of NO synthase). This conclusion is not superficial, being inferred from the results of more than 20-year in-depth studies into the nature of cytotoxic activity of immunocompetent cells and their role as mediators of cell-mediated immunity.

Studies by Hibbs et al. and Keller et al. [66-69] demonstrated that activated macrophages are indeed able to exert cytotoxic effects on malignantly transformed cells and tissues. More recent studies by Hibbs and coworkers shed additional light on cytotoxic effects of L-arginine able to generate nitrite [69] and NO responsible for cytotoxic behaviour of activated macrophages towards tumour cells and tissues [70,71]. And, finally, a detailed analysis of EPR spectra of activated macrophages established that this process is accompanied by the formation of EPR-active protein-bound M-DNIC detectable by the characteristic signal at 2.03 [72-75] (Figure 4).

For the first time, M-DNIC were detected by B. Commoner and coworkers in the livers of rats treated with different hepatocarcinogenic agents [62] and identified by a characteristic 2.03 signal defined by the authors as a specific indicator of malignant transformation in animals and man. However, our early studies dating from 1964-65 revealed that the 2.03 signal is characteristic not only of malignantly transformed, but also of normal (e.g., yeast) cells [76-78] (Figure 5).

In our studies, the 2.03 signal was detected for the first time in the livers of rabbits and pigeons as long ago as 1967 (Figure 5) [78]. In exactly the same period, we succeeded in demonstrating that the complexes able to generate the 2.03 signal in animal and bacterial organisms represent DNIC with thiol-containing ligands [79]. This hypothesis was corroborated by more recent reports from $\mathrm{B}$. Commoner's laboratory $[63,80]$.

In the 1990's, i.e., by the time when NO was recognized not only as an effector of cell-mediated immunity, but also as one of the most universal regulators of an immense diversity of physiological and biochemical processes occurring in living organisms, the 2.03 signal was detected in many cultured human and animal cells and tissues able to produce NO from L-arginine or containing endogenous or exogenous NO [72-75,81-96]. In exactly the same period, M-DNIC with thiol-containing ligands gained recognition as compounds responsible for stabilization, deposition and transfer of NO to its biological targets [19-22,24-26,96-100).

The role of NO depots in these studies was assigned to proteinbound DNIC, while low-molecular DNIC act as a vehicle for targeted delivery of NO to various body cells and tissues. The relative content of both forms of DNIC was defined as an equilibrium concentration ratio between protein-bound and low-molecular thiols.

The results obtained in these studies testified to the widespread occurrence of DNIC with thiol-containing ligands (predominantly, of B-DNIC) in animal organisms [21,26]. This fact and very high biological activity of DNIC comparable to the biological activity of the system of endogenous NO with regard to dose and the immense diversity of metabolic reactions controlled by them led one of the authors of this review to suggest that DNIC with thiol-containing ligands represent a «working» form of endogenous NO in human and animal organisms [26].

Supporting evidence for the hypothesis according to which DNIC with thiol-containing ligands play the role of cytotoxic effectors of cell-mediated immunity in living systems, was obtained in the study by Drapier et al. dating back to 1991 [75]. This study was carried out on activated macrophages of mice infected with Bacillus Calmette-Guerin as well as on macrophages activated in vitro by $\gamma$-interferone cocultured with murine leukemia cells L1210. In both cases, incubation with murine macrophages was accompanied by the appearance in L1210 cells of appreciable amounts of protein-bound M-DNIC detectable by an intense 2.03 signal (Figure 6). 


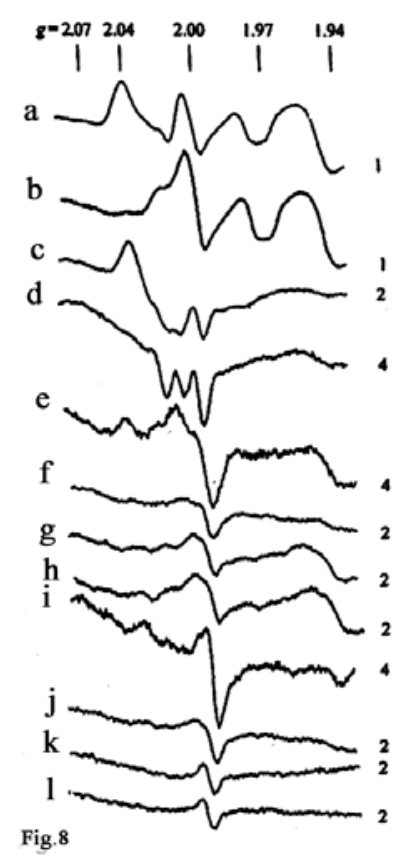

Figure 8: The EPR spectra recorded at $77 \mathrm{~K}$ in tissue samples of Lewis carcinoma and other organs of tumour-bearing mice both treated $(\mathrm{a}, \mathrm{c}, \mathrm{e}$, $\mathrm{g}, \mathrm{i}, \mathrm{k}$ ) and untreated (b, $\mathrm{d}, \mathrm{f}, \mathrm{h}, \mathrm{j}, \mathrm{l}$ ) with B-DNIC: $\mathrm{a}, \mathrm{b}$ - liver; $\mathrm{c}, \mathrm{d}$ - Lewis carcinoma; e, f - spleen; g, h - brain; i, j-lung; k, I - blood.. The 2.04 signal (Spectra a, c, e and i) was generated by protein-bound M-DNIC; the 2.0 signal (in all spectra), by free-radical centers; the 1.97 signal (Spectra a and b), by molybdenum complexes); the 1.94 signal (in all spectra except Spectra k and I), by iron-sulfur proteins; the 2.07-1.97 signal with a triplet hyperfine structure (Spectra c and d) by nitrosyl complexes of heme-containing proteins. Right side: amplification of the radiospectrometer (in arb. units) [54]

No M-DNIC were detected in L1210 cells in the absence of activated macrophages. After fractionation of L1210 cells, M-DNIC were predominantly localized in the mitochondrial fraction, which led us to conjecture that their formation is a result of interaction between NO generated by activated macrophages and iron-sulfur components of the mitochondrial respiratory chain. The possibility of M-DNIC formation from weakly bound iron (so-called labile iron pool) must not be ruled out either [75]

These studies [62-75] provided conclusive evidence in favour of the earlier proposed hypothesis on the crucial role of DNIC with thiol-containing ligands in cytotoxic activity of the immune system, in inhibition of malignant growth, in particular.

\section{Effects of $\mathrm{NO}$ and $\mathrm{NO}^{+}$as components of DNIC with thiol-} containing ligands on apoptosis in tumour cells

As mentioned earlier in the Introduction chapter, the biological activity of mono- and binuclear forms of DNIC with thiol-containing ligands (M- and B-DNIC, respectively) is determined by their ability to act as $\mathrm{NO}$ and $\mathrm{NO}^{+}$donors in human and animal organisms [2026]. Based on these findings, we thought it expedient to clarify some aspects of our own views on this problem and the data according to which DNIC with thiol-containing ligands can indeed play the role of $\mathrm{NO}^{+}$donors by virtue of their ability to generate S-nitrosothiols (RSNO) both in the presence and in the absence of oxygen.

In the paradigm of our mechanism of formation of M-DNIC

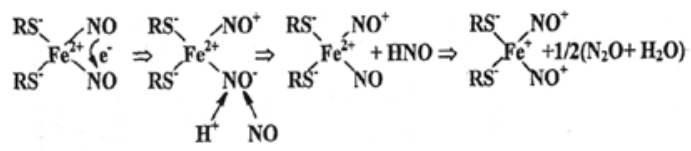

Scheme 1: The hypothetical mechanism of formation of the paramagnetic (EPR-active) mononuclear form of DNIC with thiol-containing (RS) ligands by a reaction of gaseous $\mathrm{NO}$ with the $\mathrm{Fe}^{2+}$-thiol mixture $[102,103]$.

with thiol-containing (RS-) ligands by a reaction between $\mathrm{Fe}^{2+}$, RS and gaseous NO (Scheme 1) and in terms of the Enemark-Feltham presentation [101], the electron shell of M-DNIC is described by the formula $\left\{\mathrm{Fe}(\mathrm{NO})_{2}\right\}^{7}$, i.e., it represents a structure with the $\mathrm{d}^{7}$ electronic configuration of the iron atom, while $\mathrm{M}$ - and $\mathrm{B}-\mathrm{DNIC}$ are described by the formulas $\left[\left(\mathrm{RS}_{2}^{-}\right)_{2} \mathrm{Fe}^{+}\left(\mathrm{NO}^{+}\right)_{2}\right]$ and $\left[\left(\mathrm{RS}^{-}\right)_{2} \mathrm{Fe}_{2}{ }^{+}\left(\mathrm{NO}^{+}\right)_{4}\right]$, respectively $[21-26,48,102,103]$.

According to this Scheme, the transition of the original $\mathrm{Fe}^{2+}(\mathrm{NO})_{2}$ fragment with an even number of the outer shell electrons and the diamagnetic $\mathrm{d}^{8}$ electronic configuration of the iron atom into a state with an odd number of electrons is a result of disproportionation of NO ligands, viz., transfer of one electron from one NO ligand to the other and substitution of the nitroxyl ion ( $\mathrm{NO}^{-}$) generated thereupon for the neutral molecule of NO. Under these conditions, the number of outer shell electrons in the $\mathrm{Fe}(\mathrm{NO})_{2}$ fragment diminishes to 7 as a result of which the latter turns into paramagnetic and acquires a $\mathrm{d}^{7}$ electronic configuration of the iron atom, whereas M-DNIC formed in the process are characterized by the formula $\left[\left(\mathrm{RS}^{-}\right)_{2} \mathrm{Fe}^{+}\left(\mathrm{NO}^{+}\right)_{2}\right]$.

As for B-DNIC, their formation is a result of dimerization of M-DNIC by Equation 1:

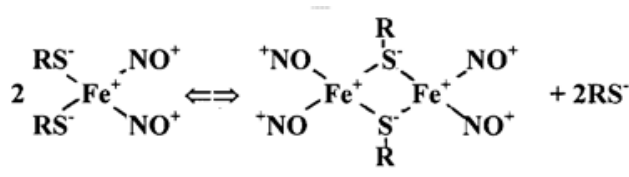

Equation $1[21,22,102,103]$

Based on the above-said, the chemical equilibrium between thioliron-dinitrosyl fragments of M- and B-DNIC and their constituent components can be presented as shown in Scheme 2.

According to this Scheme, the transfer of an electron from the $\mathrm{Fe}^{+}$ion to one of the nitrosyl ligands is accompanied by a release of the latter in the form of a neutral volatile molecule of NO, while the second nitrosyl ligand leaves the iron-dinitrosyl fragment in the form of a nitrosonium ion $\left(\mathrm{NO}^{+}\right)$; its interaction with thiol gives an appropriate S-nitrosothiol (RS-NO). This mechanism is responsible for the S-nitrosating effect on DNIC.

The results of our study [21-25] suggest that $50 \%$ of nitrosyl ligands are present in DNIC in the form of $\mathrm{NO}^{+}$ions, while the other $50 \%$ represent neutral molecules of $\mathrm{NO}$, as could be evidenced from the amount of GS-NO formed in acidified aqueous solutions of decomposing B-DNIC with glutathione [23].

\section{$\left[\left(\mathrm{RS}_{2} \mathrm{Fe}^{+}\left(\mathrm{NO}^{+}\right)_{2}\right] \Leftrightarrow \mathrm{Fe}^{2+}+\mathrm{NO}+\left(\mathrm{RS}^{\left.-\mathrm{NO}^{+}\right)}+\mathrm{RS}\right.\right.$}

Scheme 2: The chemical equilibrium between (RS) $\mathrm{Fe}^{+}\left(\mathrm{NO}^{+}\right)_{2}$ fragments of DNIC with thiol-containing ligands with the $d^{7}$ electronic configuration of the iron atom and their constituent components [21,22,102,103]. 

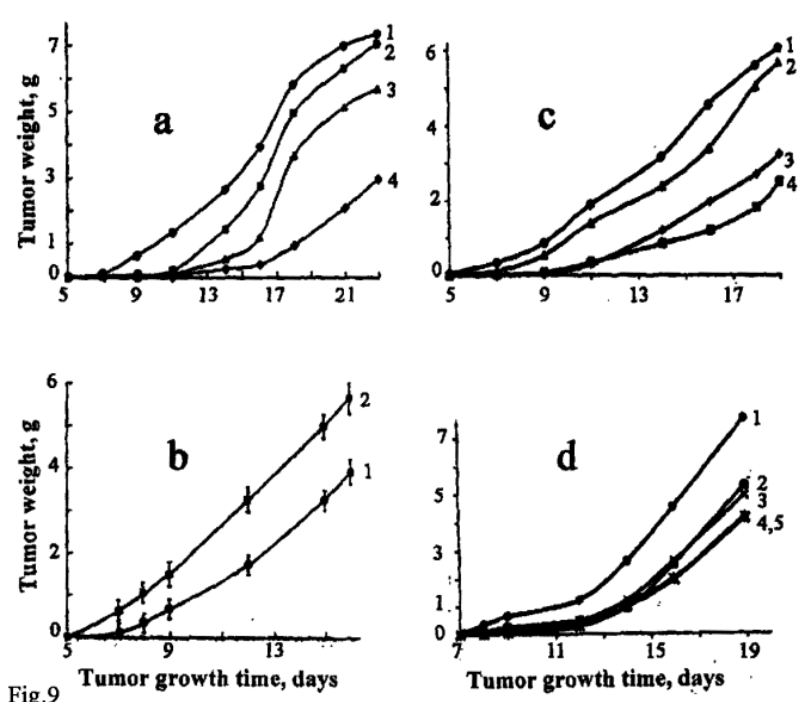

Fig. 9

Figure 9: The antitumor effects of $\mathrm{i} / \mathrm{v}$ injected B-DNIC with glutathione $(a-c)$ and GS-NO (d) on the growth of transplanted Lewis carcinoma in mice treated $\mathrm{i} / \mathrm{v}$ with different doses of the drugs: (a) 20, 10 and $2 \mu \mathrm{moles} / \mathrm{kg}$ of B-DNIC (Curves 2-4); (b) $100 \mu$ moles/kg of B-DNIC (Curve 2); (c) 2.0, 1.0 and $0.5 \mu \mathrm{moles} / \mathrm{kg}$ of B-DNIC (Curves 2-4); (d) 20, 10 and $1 \mu \mathrm{moles} / \mathrm{kg}$ of GS-NO (Curves 2-4). Curve $5-\mathrm{i} / \mathrm{v}$ administration of B-DNIC at the dose of 1 $\mu$ moles/kg. Curves 1 - control (without DNIC or GS-NO) [117]. Experiments $\mathrm{a}$ and $\mathrm{b}$ were carried out in January-February, experiments $c$ and $d$, in April.

Other studies designed to investigate different effects of DNIC with thiol-containing ligands established that DNIC exert both beneficial (antiapoptotic) [92] and cytotoxic (proapoptotic) [50, 104] effects on cultured normal and malignantly transformed cells. One of these publications [92] is devoted to apoptosis induced by treatment of cultured murine macrophages (RAW264.7 cells) and rat liver cells treated with the NO donor, S-nitroso-N-acetylDL-penicillamine (SNAP). In this study, cultured RAW264.7 cells appeared to be more sensitive to SNAP than rat hepatocytes: after their treatment with micromolar doses of the NO donor, RAW264.7 cells contained activated caspase- 3 and mitochondrial cytochrome $\mathrm{C}$ recognized as specific markers of apoptosis. Liver cells displayed no apoptosis-specific changes after treatment with millimolar and lower concentrations of SNAP. However, higher concentrations of SNAP induced death of liver cells by a necrotic (but not apoptotic) mechanism. After the increase in the concentration of non-heme iron (by incubation in high-Fe ${ }^{2+}$ media), RAW264.7 cells began to respond similarly to SNAP treatment. These changes in the RAW264.7 behaviour were accompanied by enhanced synthesis of M-DNIC with thiol-containing ligands also observed in rat liver cells non-incubated in high- $\mathrm{Fe}^{2+}$ media.

These findings led us to suggest that M-DNIC possess the ability to suppress the activity of caspase- 3 by triggering S-nitrosation of its thiol groups. This hypothesis was confirmed by the results of experiments designed to investigate the inhibiting effect of synthetic M-DNIC with cysteine on caspase-3. According to Scheme 2, M-DNIC induced S-nitrosation of caspase- 3 by acting on thiol groups of $\mathrm{NO}^{+}$ions released from DNIC. A similar S-nitrosating effect of DNIC was established for other thiol-containing proteins [105-107].

As regards cytotoxic proapoptotic activity of M-DNIC, its existence was established for human prostate carcinoma PC-3 and cultured tumour cell lines PC-3, SKBR-3 and RL5866 [104] as well as for cultured human renal carcinoma (Jurkat) cells [50]. The dose-dependent cytotoxic proapoptotic effect of M-DNIC with thiol-containing ligands $\left(\mathrm{S}_{(}\left(\mathrm{CH}_{2}\right)_{2} \mathrm{OH}\right.$ and $\left.\mathrm{S}\left(\mathrm{CH}_{2}\right)_{2} \mathrm{NH}_{3}\right)$ [104] was established for all tumour cell lines tested in this study; their $\mathrm{LD}_{50}$ values were equal to $\sim 20 \mu \mathrm{M}$ (PC-3) and $\sim 40 \mu \mathrm{M}$ (SKBR-3 and RL5866). It follows therefrom that this effect is induced by conversion of neutral NO molecules into cytotoxic peroxynitrite in the course of their interaction with the superoxide. The possibility that NO release from DNIC was initiated by treatment of DNIC with endogenous iron chelators should not be ruled out either.

Very interesting results were obtained in the study by Kleschyov et al. [49]. These authors succeeded in demonstrating that the proapoptotic effect of M-DNIC with thiosulfate on Jurkat cells does not depend on the presence in these complexes of the antiapoptotic protein $\mathrm{Bcl}-2$ able to suppress apoptosis induced by $\mathrm{NO}$ and some of its donors [108]. It was concluded that the proapoptotic effect of DNIC with thiol-containing ligands is determined by $\mathrm{NO}^{+}$ ions generated by these complexes according to Schemes 1 and 2 rather than by NO molecules released from decomposing DNIC. This hypothesis was confirmed by experiments with treatment of Jurkat cells with $\mathrm{N}$-methyl-D-glucamine dithiocarbamate (MGD), a water-soluble iron chelator devoid of the ability to penetrate into the cell interior. Under these conditions, MGD treatment initiated the conversion of M-DNIC into mononitrosyl iron complexes with MGD (MNIC-MGD) localized in the extracellular space.

The formation of MNIC-MGD was provoked by the transfer of the $\mathrm{Fe}^{2+}$-mononitrosyl fragment (Fe-NO) from DNIC to MGD and the concomitant release of $\mathrm{NO}^{+}$ions able to S-nitrosate thiols, e.g., thiol-containing proteins localized on the outer surface of the cellular membrane. As it is known, S-nitrosation of thiol-containing proteins shifts the redox equilibrium between thiols and disulfide groups towards oxidation, which initiates apoptosis [109-111].

These data altogether unequivocally suggest that by virtue of their ability to donate $\mathrm{NO}$ and $\mathrm{NO}^{+}$ions DNIC with thiol-containing ligands can both express and suppress apoptosis in tumour cells. On entering the cell, $\mathrm{NO}$ and $\mathrm{NO}^{+}$ions in DNIC begin to initiate or to suppress apoptosis as a result of conversion of $\mathrm{NO}$ molecules into cytotoxic peroxynitrite or due to S-nitrosation of caspase- 3 by $\mathrm{NO}^{+}$ ions. If for one reason or another DNIC are unable to penetrate into the intracellular space, $\mathrm{NO}$ and $\mathrm{NO}^{+}$ions generated from them produce a proapoptotic effect on tumour cells and no other.

The discovery of the ability of DNIC with thiol-containing ligands to suppress the growth of tumour cells during their in vitro culturing does not by any way mean that DNIC would produce similar effects in vivo, chiefly because in living organisms tumour growth is under a strict control of cell-mediated immunity. The effect of the latter on tumour growth can be neglected only under the stipulation that in living organisms the immune system recognizes "nonself" malignantly transformed cells as "self" and does not take any preventive measures in order to suppress their growth.

In actual fact, this condition cannot be realized. Even very early studies of malignant tumours by the EPR method detected intense EPR signals in tissue samples of tumour-bearing animals; these 
signals corresponded to nitrosyl complexes of hemoproteins, e.g., hemoglobin or myoglobin [112-114] suggesting that animal cells respond to malignant changes by activation of NO synthases (NOS) able to produce endogenous NO and thus initiate death of tumour cells. However, this conclusion applies strictly and exclusively to fairly young organisms with unimpaired functions of the immune system. In older organisms whose immune system weakens with age, endogenous NO triggers crucial changes in the system of cellmediated immunity, being unable to suppress tumour growth because of its low concentration, eventually resulting in uncontrolled growth of malignantly transformed cells by a hitherto non-established mechanism. In this context, in-depth studies of miscellaneous effects of NO donors including DNIC with thiol-containing ligands whose endogenous derivatives are formed in living organisms in the natural way [19-22,24-26] are of paramount importance, since they may provide vitally important information about mechanism(s) responsible for inhibition of malignant growth.

Our model study of solid Lewis carcinoma induced by treatment (intraperitoneal or subcutaneous) of mice with B-DNIC with glutathione was the first step in this direction. Such treatment significantly retarded the growth of transplanted subcutaneous tumours, however, only at the initial stages after which the malignant process recommenced (Figure 6a-6c) [54-56].

The inhibiting effect of B-DNIC on tumour growth was found to be dose-dependent and was especially well-pronounced in $80 \%$ of

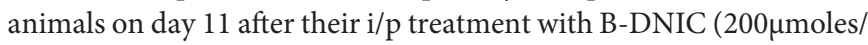
$\mathrm{kg}$ as calculated per one iron atom) [55]. In the majority of cases, B-DNIC $(100 \mu$ moles $/ \mathrm{kg})$ were injected two times a day.

\section{Antitumour effects of i/p injected B-DNIC with glutathione in a model of transplanted murine solid Lewis carcinoma}

In this study, EPR measurements were performed on day 10, $1 \mathrm{~h}$ after $\mathrm{i} / \mathrm{p}$ treatment of mice with B-DNIC and were accompanied by the appearance in the EPR spectra of a characteristic 2.03 signal corresponding to the paramagnetic form of DNIC (M-DNIC) (Figure $8 \mathrm{a}, 8 \mathrm{c}, 8 \mathrm{e}$, and $8 \mathrm{i}$ ) in tissue samples of liver, Lewis carcinoma, spleen and lung, respectively [54]. This signal was generated in the course of the transfer of paramagnetic $\mathrm{Fe}(\mathrm{NO})_{2}$ fragments from B-DNIC to thiol groups of proteins. The unchanged shape of the 2.03 signal with the increase in the registration temperature from $77 \mathrm{~K}$ to ambient temperature testified to the protein origin of B-DNIC and was attributed to low mobility of the protein globule of M-DNIC insufficient for averaging the anisotropy of the g-factor of the 2.03 signal, which determines its shape [115].

Of special notice is the drastic difference between M-DNIC concentrations in tumour tissues $(\sim 1.2 \mu$ moles $/ \mathrm{kg}$ of wet tissue $)$ estimated by the intensity of the 2.03 signal, on the one hand, and their concentrations in the spleens and lungs ( 0.3 and $0.25 \mu$ moles/ $\mathrm{kg}$, respectively), on the other hand. Their comparison points to high selectivity of B-DNIC distribution in animal tissues and their predominant accumulation in tumour cells.

In the control group (B-DNIC-untreated animals), all EPR spectra of tumour samples examined in this study [54] contained an EPR signal with a triplet hyperfine structure (HFS) (Figure 8d) characteristic of nitrosyl complexes of hemoproteins; a similar signal was detected earlier in other malignant tissues [112-114]. The concentration of nitrosyl complexes of hemoproteins in Lewis carcinoma cells was $9 \mu \mathrm{moles} / \mathrm{kg}$ of wet tissue. A similar signal with triplet HFS and distorted shape was detected in EPR spectra of tumour tissues of B-DNIC-treated mice (Figure 8c) [54].

Subcutaneous $(\mathrm{s} / \mathrm{c})$ treatment of mice with B-DNIC with glutathione had the same effect on the growth of Lewis carcinoma as in the case of $i / p$ treated animals. The rate of tumour growth in animals treated with 100 moles/kg of B-DNIC was steadily decreasing during the first 14 days of treatment and reached the control level (data not shown) [54]. The average lifespan in the experimental group exceeded control by $30 \%$ irrespective of the treatment mode $(\mathrm{s} / \mathrm{c}$ or i/p) $[55,56]$.

A similar effect was observed in the group of GS-NO-treated rats. However, in this case the inhibiting effect of GS-NO was attenuated with the increase in the drug dose from 200 to $400 \mu \mathrm{moles} / \mathrm{kg}$ (Figure 7d) [55]; the same regularity was observed in our EMT studies [53].

We attributed this phenomenon to impaired immune system of animals as a result of a transfer of NO generated from spontaneously decomposing GS-NO to both malignantly transformed and normal tissues including immunocompetent cells. Inactivation of the latter as a result of the aforesaid transfer is a plausible explanation for enhanced growth of tumour tissues. As for B-DNIC, they transferred NO preferentially to tumour cells as it might be inferred from their selective decomposition by endogenous iron chelators produced by tumour cells in order to provide themselves with iron.

Similar results illustrating antitumour activities of B-DNIC and GS-NO were obtained in experiments with transplanted adenocarcinoma Ca-755 [56] (Figure 7e,7f).

These data suggest that in contrast to non-malignant endometrial tumours (EMT) whose growth was fully suppressed by $\mathrm{i} / \mathrm{p}$ treatment of rats with 10-fold daily doses of B-DNIC with glutathione (10-12 $\mu$ moles $/ \mathrm{kg}$ ) [51-53], in mice treated with much higher doses of B-DNIC (100-200 $\mu$ moles/kg) short-term (7-11 days) discontinuation of tumour growth was followed by a relapse, the rate of this process exceeding control values (Figure 7).

What is the reason for the higher resistance of murine tumour cells to B-DNIC, which in the given experimental series were used as NO donors? One of possible explanations is that tumour cells might develop a system of antinitrosative protection similar to that detected in many bacterial and mycobacterial species [116]. This system responds to NO by expression of antinitrosative protection proteins (predominantly, of heme-containing ones), which possess an ability to oxidize or reduce $\mathrm{NO}$ to $\mathrm{NO}_{2}$ and $\mathrm{N}_{2} \mathrm{O}$, respectively, and thus initiate NO release from bacterial cells. A similar protective system could be formed in tumour cells of B-DNIC-treated animals, however, only in a very small cell population, since the absolute majority of cells die being unable to respond to B-DNIC treatment by generation of antinitrosative protection proteins. After the first 7-11 days, tumour growth discontinued, but soon thereafter the proliferative activity of NO-resistant cells was resumed as a result of which enhanced tumour growth persisted in the subsequent periods. These findings led us to assume that the differences in the tumour mass between control and experimental groups were indeed due to inhibition of tumour growth, 
which manifested itself in a decrease of the population of tumour cells at the initial stages of tumour growth (Figure 7).

Such a peculiar response of malignantly transformed cells to DNIC resembles in many features the situation observed during chemotherapy of malignant tumours in human beings where initial inhibition of tumour growth is followed by recurrence due to enhanced proliferative activity of survived drug-resistant malignant cells. From this standpoint, DNIC with thiol-containing ligands as candidates for antitumour drugs should be included in a long list of chemotherapeutic drugs able to retard (but not fully inhibit) tumour growth.

The discovery made in 2016 by a group of Taiwanese investigators headed by Prof. W-F. Liaw [104] helped us overcome the deadlock of our failures in 2014-2015 [54-56]. These authors succeeded in demonstrating a potent antitumour effect of water-soluble M-DNIC where the role of thiol-containing ligands was played by the

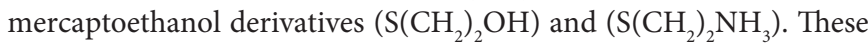
model studies were designed to investigate antitumour effects of $\mathrm{i} / \mathrm{v}$ injected M-DNIC on the growth of human prostate carcinoma (PC3) implanted to mice. Being administered $i / v$ to mice at the dose of $\sim 0.8 \mu$ moles $/ \mathrm{kg}$ (once every 3 days, for 21 days, totalling 7 injections), M-DNIC effectively (by 60 and 95\%) suppressed tumour growth on days 7 and 21, respectively. In this study, inhibition of tumour growth was a result of apoptotic death of tumour cells, as could be evidenced from the results of morphological and immunochemical studies of tissue samples from M-DNIC-treated mice. These investigators also reported on cytotoxic activity of M-DNIC able to induce death of cultured tumour cells (lines PC-3, SKBR-3 and CRL5866) by the apoptotic mechanism $\left(\mathrm{IC}_{50}=18.8,42.9\right.$ and $38.6 \mu \mathrm{M}$, respectively).

These studies demonstrated that in contrast to $\mathrm{i} / \mathrm{p}$ administered B-DNIC with glutathione, water-soluble M-DNIC with mercaptoethanol-containing ligands fully inhibited the growth of human prostate carcinoma in mice when injected on day 21 at incommensurately lower doses $(<1 \mu$ mole $/ \mathrm{kg})$. This outstanding effect can be due to a number of factors, such as different sensitivity of model tumours to treatment, specific peculiarities of DNIC, route of administration (i/p or i/v), and so on.

Our studies of a model of murine Lewis carcinoma performed under conditions resembling those used in [103] established that $\mathrm{i} / \mathrm{v}$ administration of B-DNIC with glutathione is much more effective in improving their antitumour effect than the $\mathrm{i} / \mathrm{p}$ route.

\section{Antitumour effects of i/v injected B-DNIC with glutathione in a model of transplanted Lewis carcinoma in mice}

Intravenous treatment of mice with different doses of B-DNIC with glutathione $(20,10$ and $2 \mu$ moles $/ \mathrm{kg}$; 5 times daily, for 14 days, with 2-3 day intervals) was accompanied by complete (100\%) inhibition of tumour growth throughout the 11-day observation period at all drug doses, as could be judged from the mass of Lewis carcinoma (Figure 9) [117]. However, on day 16 the inhibiting effect of B-DNIC diminished to 30,70 and $90 \%$ with a further decrease by 4, 22 and $60 \%$, respectively, on day 23 (Figure 9a). These findings are at variance with those obtained in the studies by Liaw et al., where inhibition of tumour growth increased with time, while in our experiments this parameter showed a strong tendency to decrease. As in the case of $\mathrm{i} / \mathrm{p}$ administration of B-DNIC, the maximum (100\%) inhibition of tumour growth previously observed at the initial stages, changed after $\mathrm{i} / \mathrm{v}$ injection and was manifested in enhanced tumour growth with time. The same was observed in our studies in which GSNO were used instead of B-DNIC with glutathione (Figure 9d) [117].

From Figures 7 and 9 it follows that the use of $i / v$ instead of $i / p$ treatment changed the dose dependence of B-DNIC effect on tumour growth to the opposite. Whereas after $\mathrm{i} / \mathrm{v}$ treatment the inhibiting effect of B-DNIC increased with a decrease of the drug dose, after the switchover to the $\mathrm{i} / \mathrm{p}$ route an inverse correlation was established. This difference was especially apparent after $\mathrm{i} / \mathrm{v}$ injection of the $100 \mu$ moles/ $\mathrm{kg}$ B-DNIC dose when enhanced tumour growth occurred instead of inhibition observed after i/p injection (Figure $7 b$ ).

Obviously, the low efficiency of the $\mathrm{i} / \mathrm{p}$ route can be explained by the fact that only a very small amount of low-molecular B-DNIC with glutathione was transferred from the abdominal cavity to circulating blood. As a result of a transfer of their $\mathrm{Fe}(\mathrm{NO})_{2}$ groups to thiol groups of proteins, the majority B-DNIC could be represented by protein-bound DNIC localized in the abdominal cavity and the small intestine. As for glutathione, it could also be retained in the abdominal cavity due to the inability to penetrate effectively through cell membranes. Consequently, the concentration of low-molecular DNIC responsible for targeted delivery of $\mathrm{Fe}(\mathrm{NO})_{2}$ groups to tumour cells and subsequent effects of $\mathrm{NO}$ and $\mathrm{NO}^{+}$ions released from $\mathrm{Fe}(\mathrm{NO})_{2}$ groups of DNIC were insufficient for manifestation of their cytotoxic effects upon i/p administration. In contrast, the $\mathrm{i} / \mathrm{v}$ route ensured effective delivery of both B-DNIC and free glutathione to circulating blood. As a result, the majority of low-molecular DNIC could successfully deliver their $\mathrm{Fe}(\mathrm{NO})_{2}$ groups to tumour cells and thus provide them with sufficient amounts of $\mathrm{NO}$ and $\mathrm{NO}^{+}$ions (Scheme 2).

All the aforementioned studies were carried out in wintertime (February). In a special series of our experiments conducted in April, inhibiting effects of B-DNIC on tumour growth increased with a decrease in the drug dose (to $0.5 \mu$ moles $/ \mathrm{mg}$ ). At $2 \mu$ moles/ mg B-DNIC, the inhibiting effect was strongly attenuated (Figure 9c).

Hence, the use of $i / v$ treatment of experimental animals with DNIC instead of $\mathrm{i} / \mathrm{p}$ treatment made it possible to significantly reduce the drug dose able to suppress the growth of malignant tumours even at the initial stages. However, our studies turned out to be less successful than those conducted by the Prof. Liaw's team [103]. In the aforecited study, DNIC with thiol-containing ligands effectively inhibited the growth of transplanted malignant tumours unattainable in our studies.

What was the reason for the outstanding success of the Chinese investigators? For one thing, cells of transplanted carcinoma PC-3 appeared to be less resistant to DNIC than tumour cells examined in our study. Second, potent effect of DNIC on PC-3 might be related to the nature of thiol ligands or, more particularly, to the small size of ethylmercaptane molecules used as ligands for DNIC by the Taiwanese investigators. Ethylmercaptane ligands could also be responsible for high S-nitrosating activity of DNIC, although their mechanisms of action still remain to be explored. It remains to be hoped that in-depth studies of antitumour effects of DNIC as $\mathrm{NO}^{+}$, 
but not as NO donors will give more encouraging results and give us grounds to assert that DNIC with thiol-containing ligands hold considerable promise as candidate anticancer drugs.

\section{Acknowledgement}

This work has been carried out in the framework of the State Programs of the Russian Federal Agency for Scientific Organizations (0082-2014-0001, No. AAAA-A17-117040610310-6 0082-2014-0008 and No. AAAA-A17-117040310008-5). The study is sponsored also by Russian academic excellence project " $5-100$ " and supported by the Russian Foundation for Fundamental Research (Grant No. 1804-00059a) and the Russian Scientific Foundation (Grant No. 16-1310295).

\section{References}

1. JB Hibbs, RR Taintor, Z Vavrin, EM Rachlin. Nitric oxide: a cytotoxic activated macrophage effector molecule. Biochim Biophys Res Comm. 1988; 157: 87-94

2. DJ Stuehr, CF Nathan. Nitric oxide: a macrophage product responsible for cytostasis and respiratory inhibition in tumor target cells. J Exp Med. 1989; 169: 1543-1555.

3. R Keller, M Geiges, R Keist. L-arginine-dependent reactive nitrogen intermediates as mediators of tumor cell killing by activated macrophages. Cancer Res. 1990; 50: 1421-1425.

4. N Lavnikova, J-C Drapier, DL Laskin. A single exogenous stimulus activates resident rat macrophages for nitric oxide production and tumor cytotoxicity. $\mathrm{J}$ Leukocyte Biol. 1993; 54: 322-328.

5. DA Wink, YVodovotz, JA Cook, MC Krishna, S Kim, D Coffin. The role of nitric oxide chemistry in cancer treatment. Biochemistry. 1998; 63: 802-809.

6. S Moochhala, A Rainakova. Role of nitric oxide in cancer biology. Free Rad Res. 1999; 31: 671-679.

7. S Mocellin, $V$ Bronte, D Nitti. Nitric oxide, a double edged sword in cance biology: searching for therapeutic opportunities. Med Res Rev. 2007; 27 317-352.

8. MM Reynolds, SD Witzeling, VB Damodaran, TN Medeiros, RD Knodle, MA Edwards, et al. Applications for nitric oxide in halting proliferationof tumor cells. Biochim Biophys Res Comm. 2013; 431: 647-651.

9. J Muntane, AJ De la Rosa, LM Marin, FJ Padillo. Nitric oxide and cell death in liver cancer cells. Mitochondrion. 2013; 13: 257-262.

10. AJ Burke, FJ Sullivan, FJ Giles, SA Glynn. The yin and yang of nitric oxide in cancer progression. Carcinogenesis. 2013; 34: 505-512.

11. BK Sinha. Nitric oxide: friend or foe in cancer chemotherapy and drug resistance: a perspective. Cancer Science \& Therapy. 2016; 8: 244-251.

12. SK Choudhari, M Chaudhari, S Bagde, AR Gadbail, V Joshi. Nitric oxide and cancer: a review. World J Surg Oncology. 2013; 11: 11-118.

13. B Bonavida, H Garban. Nitric oxide-mediated sensitization of resistant tumo cells to apoptosis by chemo-immunotherapeutics. Redox Biol. 2015; 6: 486494.

14. C-F Chang, AR Diers, N Hogg. Cancer cell metabolism and the modulating effect of nitric oxide. Free Rad Biol Med. 2015; 79: 324-336.

15. R Salimian, A Achreja, D Nagrath. Nitric oxide: The forgotten child of tumor metabolism. Trends Cancer. 2017; 3: 659-672.

16. Z Huang, Y Zhang. Nitric oxide donor-based cancer therapy: advances and prospects. J Med Chem. 2017; 60: 7617-7635.

17. R Gonzalez, FJ Molina-Ruiz, JA Barcena, CA Padilla, J Muntane. Regulation of cell survival, apoptosis, and epithelial-to-mesenchymal transition by nitric oxide-dependent post-translational modifications. Antioxid Redox Signal. 2017.

18. K Ghimire, HM Altman, AC Straub, JS Isenberg. Nitric oxide: what's new to
NO. Am J Physiol. 2017; 312: C254-C262.

19. AF Vanin, AL Kleschyov. EPR studies and biological implications of nitrosyl nonheme iron complexes, in S Lukiewicz and J L Zweier (Eds). Nitric Oxide in Transport and Anti-Tumor Defense, Kluwer Acad Pub. 1997: pp 49-82.

20. AF Vanin, E van Faassen. DNICs: physico-chemical properties and their observations in cells and tissues, in E van Faassen, AF Vanin (Eds). Radicals for Life: The Various Forms of Nitric Oxide, Elsevier, Amsterdam. 2007; pp 19-73.

21. AF Vanin. Dinitrosyl iron complexes with thiolate ligands: Physico-chemistry, biochemistry and physiology, Nitric Oxide. Biol Chem. 2009; 21: 1-13.

22. AF Vanin, DSh Burbaev. Electronic and spatial structures of water-soluble dinitrosyl iron complexes with thiol-containing ligands underlying their activity to act as nitricoxide and nitrosonium ion donors. Biophys J. 2011; 14: 878236 .

23. RR Borodulin, LN Kubrina, VD Mikoyan, AP Poltorakov, VO Shvydkiy, DSh Burbaev, et al. Dinitrosyl ironcomplexes with glutathione as $\mathrm{NO}$ and $\mathrm{NO}+$ donors. Nitric Oxide Biol Chem. 2013; 29: 4-16.

24. AF Vanin. Dinitrosyl iron complexes with natural thiol-containing ligands: Physico-chemistry, Biology and Medicine, in Bioorganometallic ChemistryApplication in Drug Discovery. Biocatalysis and Imaging, Ed G Jaonen, M Salmain, Wiley Verlag. 2014: 203-238.

25. AF Vanin. Dinitrosyl iron complexes with thiol-containing ligands: physico-chemistry, biology, medicine, ANO Izhevsk Institute of Computer Investigations Izhevsk. Russia. 2016; 54: 15-29.

26. AF Vanin. Dinitrosyl iron complexes with thiol-containing ligands as a "working form" of endogenous nitric oxide. Nitric Oxide Biol Chem. 2016; 54: 15-29.

27. AF Vanin, RR Borodulin, VD Mikoyan. Dinitrosyl iron complexes with natural thiol-containing ligands in aqueous solutions: synthesis and some physicochemical characteristics (A methodological review). Nitric Oxide Biol Chem. 2017; 66: 1-9.

28. El Chazov, OV Rodnenkov, AV Zorin, VL Lakomkin, VV Gramovich, OV Vyborov, et al. Hypotensive effect of "Oxacom" containing a dinitrosyl iron complex with glutathione: animal studies and clinical trials on healthy volunteers. Nitric Oxide Biol Chem. 2012; 26: 148-157.

29. YuP Vedernikov, PI Mordvintcev, IV Malenkova, AF Vanin. Similarity between the vasorelaxing activity of dinitrosyl iron cysteine complexes and endothelium-deived relaxing factor. Eur J Pharmacol. 1992; 211: 313-317.

30. FW Flitney, LI Megson, DE Flitney, AR Butler. Iron-sulfur clustrer nitrosyls: a novel class of nitric oxide generator: mechanism of vasodilatot action on rat isolated tail artery. Brit J Pharmacol. 1992; 107: 842-847.

31. AF Vanin, VP Mokh, VA Serezhenkov, El Chazov. Vasorelaxing activity of stable powder preparations of dinitrosyl iron complexes with cysteine or glutathione. Nitric Oxide Biol Chem. 2007; 16: 322-330.

32. VL Lakomkin, AF Vanin, AA Timoshin, VI Kapelko, El Chazov. Long-lasting hypotensive action of stable preparations of dinitrosyl iron complexes with thiol-containing ligands in conscious normotensive and hypertensive rats. Nitric Oxide Biol Chem. 2007; 16: 413-418.

33. PI Mordvintcev, VG Rudneva, AF Vanin, LL Shimkevich, BI Khodorov. The inhibitory effect of low-molecular dinitrosyl iron complexes on platelet aggregation. Biokhimiya (Rus). 1986; 51: 1851-1857.

34. EB Shamova, OD Bichan, ES Drosd, IV Gorudko, SA Chizhik, KB Shumaev, et al. Regulation of functional and mechanical properties of platelet and red blood cells by nirric oxide donors. Biofizika (Rus). 2011; 56: 265-271.

35. AB Shekhter, TG Rudenko, VA Serezhenkov, AF Vanin. Dinitrosyl iron complexes with cysteine or glutathione accelerate skin wound healing. Biofizika (Rus). 2007; 52: 534-538.

36. AB Shekhter, TG Rudenko, LP Istranov, AE Guller, RR Borodulin, AF Vanin. Dinitrosyl iron complexers with glutathione incorporated into a collagen matrix as a base for the design of drugs accelerating skin wound healing. Eur J Pharm Sci. 2015; 78: 8-18. 
37. MI Remizova, NI Kochetygov, KA Kerbout, VL Lakomkin, AA Timoshin EN Burgova, et al. Effect of dinitrosyl iron complexes with glutathione onhemorrhagic shock followed by saline treatment. Eur J Pharmacol. 2011 662: $40-46$.

38. AA Andreyev-Andriyevsky, VD Mikoyan, VA Serezhenkov, AF Vanin. Penile erectile activity of dinitrosyl iron complexes with thiol-containing ligands. Nitric Oxide Biol Chem. 2011; 24: 217-223.

39. OI Pisarenko, LI Serebryakova, OV Tskitishvili, LM Studneva, AF Vanin, E Chazov. Cardio protective action of dinitrosyl iron complexes with cysteine in rats in vivo in: Proceedings of Russian Academy of Sciences. Biology. 2008; 1: 110-114.

40. YM Kim, HT Chung, RL Simmons, TR Billiar. Cellular non-heme iron content is a determinant of nitric oxide-mediated apoptosis, necrosis, and caspaseinhibition. J Biol Chem. 2000; 275: 10954-10961.

41. H Ding, B Demple. Direct nitric oxide transduction via nitrosylation of ironsulfur centers in the SoxR transcription activation. Proc Natl Acad Sci USA 2000; 97: 5146-5150.

42. SV Vasilyeva, MV Stupakova, II Lobysheva, VD Mikoyan, AF Vanin. SoxRS regulon activation in Eshericia coli by nitric oxide and its donors. Biokhimiya (Rus). 2001; 66: 1209-1214.

43. H Cruz-Ramos, J Crack, G Wu, MH Hughes, C Scott, AJ Thomson, et al. NO sensing by FNR: regulation of the Escherichia coli NO-detoxifying flawohaemoglobin. Hmp, The EMBO J. 2002; 21: 3235-3244.

44. FC Lo, CL Chen, CM Lee, MC Tsai, TT Lu, WF Liaw, et al. A study of $\mathrm{NO}$ trafficking from dinitrosyl-iron complexes to the recombinant $\mathrm{E}$ coli transcriptional factor SoxR. J Biol Inorg Chem. 2008; 13: 961-972.

45. M Fujikawa, K Kobayashi, T Kozawa. Mechanistic studies on formation of the dinitrosyl iron complex [2Fe -2S] cluster of SoxR protein. J Biochem. 2014; 156: 163-172.

46. JC Crack, J Green, AJ Thomson, NE Le Brun. Iron-sulfur clusters as biological sensors: the chemistry of reactions with molecular oxygens and nitric oxide. Acc Chem Res. 2014; 47: 3196-5205.

47. KB Shumaev, AA Gubkin, VA Serezhenkov, II Lobysheva, OV Kosmachevskaya, EK Ruuge, et al. Interaction of reactive oxygen and nitrogen species with albumin- and methemoglobin-bound dinitrosyl-iron complexes. Nitric Oxide Biol Chem. 2008; 18: 37-46

48. VI Kapel’ko, VL Lakomkin, AA Abramov, EV Lukoshkova, NA Undroninas, AY Kapchaev, VP Shirinsky. Exogenous DNIC with glutathione (Oxacom) as an antioxidant demonstrates high potential for cardioprotection during hypoxia-reoxygenation. Oxidat Med Cell Longevity. 2017; 2017: ID9456163.

49. NY Giliano, LV Konevega, LA Noskin, VA Serezhenkov, AP Poltorakov, AF Vanin. Dinitrosyl iron complexes with thiol-containing ligands and apoptosis: Sudies with HeLa cell culture. Nitric Oxide Biol Chem. 2011; 24: 151-159.

50. AL Kleschyov, S Strand, S Schmitt, D Gottfried, M Skatchkov, N Sjakste, et al. Dinitrosyl-iron triggers apoptosis in Jurkat cells Idespite overexpression of $\mathrm{Bcl}_{2}$. Free Rad Biol Med. 2006; 40: 1340-1348.

51. EN Burgova, NA Tkachev, LV Adamyan, VD Mikoyan, OV Paklina, AA Stepanyan, et al. Dinitrosyl iron complexes with glutathione suppress experimental endometriosis in rats. Eur J Pharmacol. 2014; 727: 140-147.

52. EN Burgova, NA Tkachev, OV Paklina, LV Adamyan, VD Mikoyan, AFVanin. The effect of dinitrosyl iron complexes with glutathione and S-nitrosoglutathione on the development of experimental endometriosis in rats: comparative studies. Eur JPharmacol. 2014; 741: 37-44.

53. AF Vanin, EN Burgova, LA Adamyan. Dinitrosyl iron complexes with glutathione suppress surgically induced experimental endometriosis in rats. Austin J Reproductive Medicine \& Infertility. 2015; 2: 1-7.

54. AF Vanin, LA Ostrovskaya, DB Korman, RR Borodulin, LN Kubrina, MM Fomina, et al. Anti-tumor activity of dinitrosyl iron complexes with glutathione, Biophysics. Translation from Russian. 2014; 59: 415-419.

55. AF Vanin, LA Ostrovskaya, DB Korman, VD Mikoyan, LN Kubrina, RR Borodulin, et al. Anti-nitrosativesystem as a factor of malignant tumo resistance to the cytotoxic effect of nitrogen monoxide, Biophysics. Translation from Russian. 2015; 60: 121-125.

56. AF Vanin, LA Ostrovskaya, DB Korman, LN Kubrina, RR Borodulin, MM Fomina, et al. The anti-tumor activity of the S-nitrosoglutathione and dinitrosyl iron complexes with glutathione: comparative studies. Biophysics, Translation from Russian. 2015; 60: 963-969.

57. C Badroff, B Fichtscherer, A Muelsch, AM Zeicher, S Dimeller. Selective delivery of nitric oxide to a cellular target: a pseudosubstrate-coupled dinitrosyl iron complex inhibits the enteroviral protease 2A. Nitric Oxide Bio Chem. 2001; 6: 305-312

58. M Fontecave. Ribonucleotide reductase and radical reactions. Cell Mol Life Sci. 1998; 54: 684-695.

59. JS Beckman, WH Koppenol. Nitric oxide, superoxide, and peroxynitrite: the good, the bad, and ugly. Am J Physiol. 1996; 271: C1424-C1437.

60. C Szabo, H Ischiropoulos, R Radi. Peroxynitrite: biochemistry, pathophysiology and development of therapeutics. Nat Rev. 2007; 6: 662680.

61. DR Richardson, PPonka. The moleculr mechanisms of the metabolism and transport of iron in normal and neoplastic cells. Biochim Biophys Acta. 1997; 1331: 1-40.

62. AJ Vithayhyl, B Ternberg, B Commoner. Electron spin resonance signals of rat liver during chemical carcinogenesis. Nature. 1965; 207: 1246-1249.

63. JC Woolum, B Commoner. Isolation and identification of a paramagnetic complex from livers of carcinogen-treated rats. Biochim Biophys Acta. 1970; 291: 131-140.

64. B Commoner, JC Woolum, BH Senturia, JL Ternberg. The effects of 2-acetylaminofluorene and nitrite on free radicals and carcinogenesis in rat livers. Cancer Res. 1970; 30: 2091-2097.

65. RW Chiang, JC Woolum, B Commoner. Further study of the properties of the liver protein involved in a paramagnetic complex in the livers of carcinogenictreated rats. Biochim Biophys Acta. 1972; 257: 452-460.

66. JB Hibbs Jr, LH Lambert Jr, JS Remington. Resistance to murine tumors conferred by chronic infection with intracellular protozoa, Toxoplasma gondii and Bosnoitia jellisont. J Infect Dis. 1971; 124: 587-592.

67. JB Hibbs Jr, LH Lambert Jr, JS Remington. Possible role of macrophages mediated nonspecific cytotoxicity in tumor resistance. Nat New Biol. 1972; 235: $48-50$.

68. R Keller. Cytostatic elimination of syngeneic rat tumor cells in vitro by nonspecifically activated macrophages. J Exp Med. 1973; 138: 625-644.

69. JB Hibbs Jr, RR Taintor, Z Vavrin. Macrophage cytotoxicity: role for L-arginine deiminase and imino nitrogen oxidation to nitrite. Science. 1987; 235: 473-476.

70. JC Drapier, JB Hibbs Jr. Differentiation of murine macrophages to express cytotoxicity to tumor cells results in L-arginine-dependent inhibition of mitochondrial iron-sulfur enzymes in the macrophage effector cells. J Immunol. 1988; 140: 2829-2838.

71. DJ Stuehr, SS Gross, I Sakuma, R Levi, CF Nathan. Activated murine macrophages secrete a metabolite of arginine with the bioactivity of endothelium-derived relaxing factor and the chemical reactivity of nitric oxide. J Exp Med. 1989; 169: 1011-1020.

72. JR Lancaster Jr, JB Hibbs Jr. EPR demonstration of iron-nitrosyl complex formationby cytotoxic activated macrophages. Proc Natl Acad Sci USA. 1990; 87: 1223-1227.

73. C Pellat, Y Henry, J-C Drapier. IFN-activated macrophages: detection by electron paramagnetic resonance of complexes between L-arginine-derived nitric oxide and non-heme iron proteins. Biochim Biophys Res Comm. 1990; 166: $119-125$

74. Y Henry, C Docrocq, JC Drapier, D Servent, C Pellat, A Guissani. Nitric oxide, a biological effector: electron paramagnetic resonance detection of nitrosyl-iron-protein complexes in whole cells. Eur Biophys J. 1991; 20: 1-15. 
75. J-C Drapier, C Pellat, Y Henry. Generation of EPR-detectable nitrosyl-iron complexes in tumor target cells cocultured with activated macrophages. J Biol Chem. 1991; 266: 10162-10167.

76. RM Nalbandyan, AF Vanin, LA Blumenfeld. EPR signals of a new type in yeast cells, Abstracts of the Meeting "Free Radical Processes in Biological Systems". Moscow. 1964; p18.

77. AF Vanin, RM Nalbandyan. Free radicals of a new type in yeast cells. Biofizika (Rus). 1965; 10: 167-168.

78. AF Vanin, LA Blumenfeld, AG Chetverikov. Investigations of non-heme ironcomplexes in cells and tissues by the EPR method. 1967; 12: 820-841.

79. AF Vanin. Identification of divalent iron complexes with cysteine in biological systems. Biokhimiya (Rus). 1967; 32: 829-841.

80. JC Woolum, E Tiezzi, B Commoner. Electron spin resonance study of ironnitric oxide complexes with amino acids, peptides and proteins. Biochim Biophys Acta. 1968; 160: 311-320.

81. M Lepoivre, J-M Flavan, Y Henry. Early loss of the tyrosyl radical inribonucleotide reductase of adenicarcinoma cells producing nitric oxide. J Biol Chem. 1992; 267: 22294- 22300

82. JA Corbett, MA Sweetland, JL Wang, JR Lancaster, ML McDonald. Nitric oxide mediates cytokine-induced inhibition of insulin secretion by human islets of Langerhans. Proc Natl Acad Sci USA. 1993; 90: 1731-1735.

83. AF Vanin, PI Mordvintcev, S Hauschildt, A Mulsch. The relationship between L-arginine-dependent nitric oxide synthesis, nitrite release and dinitrosyl-iron complex formation by activated macrophages. Biochim Biophys Acta. 1993; 1177: $37-42$.

84. J Stadler, HA Bergonia, M DiSilvio, MA Sweetland, TR Billiar, RL Simmons, et al. Nonheme nitrosyl-iron complex formation in rat hepatocyte: detection by EPR spectroscopy. Arch Biochem Biophys. 1993; 302: 4-11.

85. AK Nussler, DA Geller, MA Sweetland, M DiSilvio, TR Billiar, JB Madariaga, et al. Induction of nitric oxide synthesis andits reaction in cultured human and rat hepatocytes with cytokines plus LPS. Biochem Biophys Res Comms. 1993; 194: 826-835

86. Mulsch, PI Mordvintcev, AF Vanin, R Busse. Formation and release of dinitrosyl iron complexes. Biochem Biophys Res Comms. 1993; 196: 13031308

87. Y-L Geng, A-S Petersson, A Wennmalm, G Hannson. Cytokine-induced expression of nitric oxide synthase results in nitrosylatiion of heme and nonheme proteins in vascular smooth muscle cells. Exp Cell Res. 1994 214: $418-424$

88. NR Bastian, C-Y Yim, JB Hibbs, WE Samlowsky. Induction of iron-derived EPR signals in murine cancer by nitric oxide. J Biol Chem. 1994; 269: 5127 5131

89. JR Lancaster, G Werner-Felser, H Wachter. Coinduction of nitric oxide synthesis and intracellular noheme iron-nitrosyl complexes in cytokineinduced fibroblasts. Free Rad Biol Med. 1994; 16: 869-670.

90. D Muller, A Kleschyov, J-C Stoclet. Evidence for $\mathrm{N}$-acetylcysteine sensitive nitric oxide storage as dinitrosyl-iron complexes in lipopolysaccharidetreated rat aorta. Br J Pharmacol. 1996; 119: 1281-1285.

91. K Odoi, T, Akaike, H Horie, S Fujii, N Beppu, M Ogawa, H Maeda. Excessive production of nitric oxide in rat solid tumor and its implication in rapid tumor growth. Cancer. 1996; 77: 1598-1604.

92. Y-M Kim, H-T Chung, RL Simmons, TR Billiar. Cellular non-heme ironcontent is a determinant of nitric-oxide-mediated apoptosis, necrosis, and caspaseinhibition. J Biol Chem. 2000; 275: 10954-10961.

93. VD Mikoyan, VA Serezhenkov, NV Brazhnikova, LN Kubrina, GN Khachatryan, AF Vanin. Formation of paramagnetic nitrosyl complexes of nonheme iron in animal organisms with the participation of nitric oxide from exogenous and endogenous sources. Biofizika (Rus). 2004; 41: 110-116.

94. RN Watts, C Hawkins, P Ponka, RL Richardson. Nitrogen monoxide (NO)mediated iron release from cells is linked with NO-induced glutathione efflux viamultidrug resistance-associated proteins. Proc Natl Acad Sci USA. 2006
103: $7670-7675$

95. JZ Pederson, F DeMaria, PTurella, G Federici, M Mattei, R Fabrini, et al. Glutathione transferase sequestertoxic dinitrosyl-iron complexes in cells. J Biol Chem. 2007; 282: 6364-6371.

96. JC Toledo, CA Bosworth, SW Hennon, HA Mahtani, HA Bergonia, JR Lancaster. Nitric oxide-induced conversion of cellular chelatable iron intomacromolecular-bound paramagnetic dinitrosylirion complexes. J Bio Chem. 2008; 283: 28926-28933.

97. C-L Chen, W-C Ku, I-T Feng, M-L Tsai, C-Y Hsieh, W-H Hsu, et al. Nitric oxide physiological responses and delivery mechanisms probed by watersoluble Roussin`s Red Ester and $\left\{\mathrm{Fe}(\mathrm{NO})_{2}\right\} 10$ DNIC. J Am Chem Soc. 2008; 130: 10929-10938.

98. JR Hickok, S Sahni, H Shen, A Arvindt, C Antoniou, LWM Fung, DD Thomas. Dinitrosyliron complexes are the most abundant nitric oxide-derived cellular adducts: biological parameters of assembly and disappearance. Free RadBiol Med. 2011; 51: 1558-1566.

99. HC Lok, V Richardson, DS Kalinowski, Z Kovacevic, DJR Lane, DR Richardson. Glutathione S-transferase and MRP1 form an integrated system involved in the storage and transport of dinitrosyl-dithiolato iron complexes in cells. Free Rad Biol Med. 2014; 75: 14-29.

100.Z Kovacevic, S Sahni, H Lok, MJ Davies, DA Wink, DR Richardson. Regulation and control of nitric oxide (NO) in macrophages: protecting the "professional killer cells" from its own arsenal via MRP1 and GSTP1. Biochim Biophys Acta. 2017; 1861: 995-996.

101. H Enemark, RD Feltham. Principles of structure, bonding, and reactivity for metal nitrosyl. Coord Chem. 1974; 13: 339-406.

102. AF Vanin, IV Malenkova, VA Serezhenkov. Iron catalyzes both decomposition and synthesis of S-nitrosothiols: Optical and electron paramagnetic resonance studies. Nitric Oxide Biol Chem. 1997; 1: 191-203.

103. AF Vanin, AP Poltorakov, VD Mikoyan, LN Kubrina, DSh Burbaev. Polynuclear water-soluble dinitrosyl iron complexes with cysteine or glutathione ligands: electron paramagnetic resonance and optical studies. Nitric Oxide Biol Chem. 2010; 23: 136-149.

104. S-C Wu, C-Y Lu, U-L Chen, F-C Lo, T-Y Wang, Y-J Chen, et al. Watersoluble dinitrosyl iron complex (DNIC): a nitric oxide vehicle triggering cancer cell death via apoptosis. Inorg Chem. 2016; 55: 9383-9392.

105. MBoese, P Mordvintcev, AF Vanin, B Busse, A Mülsch. S-nitrosation of serum albumin by dinitrosyl-iron complex. J Biol Chem. 1995; 270: 29244 29249.

106. CA Bosworth, JC Toledo, JW Zmijevski, Q Li, JR Lancaster. Dinitrosyliron complexes and the mechanism(s) of cellular protein nitrosothiol formation. Proc Natl Acad Sci USA. 2009; 106: 4671-4676.

107. MW Foster, M Zeng, DT Hess, JS Stamler. A genetic analysis of nitrosative stress. Biochemistry. 2009; 48: 792-799.

108. V Umansky, V Schirrmacher. Nitric oxide-induced apoptosis in tumor cells. Adv Cancer Res. 2001; 82: 107-131.

109. YT Chang, CY Wu, JY Tang, CY Huang, CC Liaw, SH Wu, et al. Sinularin induced oxidative stress-mediated G2/M arrest andapoptosis in oral cancer cells. Environ Toxicol. 2017; 32: 2124-2132.

110. L Xu, H Sun, M Chang, Y Jiang, C Zhang, J Zhou, et al. MicroRNA- 145 protects follicular granulose cells against oxidative stress-induced apoptosis by targeting Krütel-like factor 4. Mol Cell Endocrin. 2017; 452: 138-147.

111. Öz, Ö Celik. Curcumin inhibits oxidative stress-induced TRPM2 channel activation, calcium ion entry and apoptosis values in SH-SY5Y neuroblastoma cells: involvement of transfection procedure. Mol Membr Biol. 2017; 33: 76-88.

112. M Brennan, T Cole, JA Sungley. A unique hyperfine ESR spectrum in mouseneoplasms analyzed by computer simulation. Proc Soc Exptl Biol Med. 1966; 123: 715-718.

113. NM Emanuel, AN Saprin, VA Shabalkin, LE Kozlova, KE Kruglyakova. Detection and investigation of a new type of ESR signal characteristic of 
some tumor tissues. Nature. 1969; 222: 165-167

114. T Maruyama, N Kataoka, S Nagase, H Nakada, H Sato, H Sasaki. Identification of three-line electron spin resonance signal and its relationship to ascites tumors. Cancer Res. 1971; 31: 179-184.

115. AF Vanin, VA Serezhenkov, VD Mikoyan, MV Genkin. The 2.03 signal as an indicator of dinitrosyl-iron complexes with thiol-containing ligands. Nitric Oxide Biol Chem. 1998; 2: 224-234.
116. J Green, VD Rolfe, LJ Smith. Transcriptional regulation of bacterial virulence gene expression by molecular oxygen and nitric oxide. Virulence. 2013; 5 : 794-809.

117. AF Vanin, LA Ostrovskaya, DB Korman, VA Rykova, NV Bluchterova, MM Fomina. Anti-tumor effect of dinitrosyl iron complexes with glutathione in murine solid- tumor model, Biophysics. Translation from Russian. 2017; 62 479-484.
Austin J Anal Pharm Chem - Volume 5 Issue 3 - 2018

ISSN : 2381-8913 | www.austinpublishing group.com

Vanin et al. @ All rights are reserved
Citation: Vanin AF, Ostrovskaya LA and Korman DB. Antitumour Activity of Dinitrosyl Iron Complexes with ThiolContaining Ligands in Animals: An Overview. Austin J Anal Pharm Chem. 2018; 5(3): 1104. 